\title{
Pembentukan Komunitas Masyarakat Pembuat Media Tanam dari Sampah Plastik Kresek
}

\author{
Establishment of a Community in the Making of Planting Media from Crackle Plastic Waste
}

Wiwit Probowati ${ }^{*}$
Ika Afifah Nugraheni ${ }^{1}$
Suryadi ${ }^{2}$
1Universitas 'Aisyiyah Yogyakarta,
Sleman, Special Region of Yogyakarta,
Indonesia
2Sayidan Agro Media, Sleman, Special
Region of Yogyakarta, Indonesia
"email: wiwitprobo@unisayogya.ac.id
Kata Kunci
Komunitas
Media Tanam
Sampah
Plastik Kresek
Keywords:
Community
Plant media
Rubbish
Plastic bag
Accepted: January 2020
Published: March 2020

\begin{abstract}
Abstrak
Program pengabdian masyarakat difokuskan pada pembentukan komunitas masyarakat yang mempunyai komitmen mengolah sampah plastik kresek menjadi media tanam (mediokres). Mediokres merupakan produk inovasi organisasi Sayidan Agro Media di kabupaten Sleman, D.I. Yogyakarta yang mampu memanfaatkan sampah plastik kresek di Tempat Pembuangan Akhir menjadi media tanam pengganti tanah. Mediokres sudah dipasarkan secara luas di Indonesia. Namun dalam proses produksi mediokres mengalami kendala, salah satunya adalah pasokan produk mediokres yang lambat dibandingkan permintaan konsumen yang banyak. Oleh karena itu komunitas mediokres yang terbentuk ini mampu membantu memenuhi stok mediokres baik untuk pemesana maupun persediaan setiap bulan. Sehingga permintaan konsumen terpenuhi.
\end{abstract}

\begin{abstract}
The focus of the community service program is the formation of communities that are committed to processing plastic rubbish materials into planting media (mediokres). Mediokres is a product of Sayidan Agro Media's organizational innovation in Sleman, D.I. Yogyakarta, which is able to utilize plastic bag rubbish at the Final Disposal Site becomes a planting medium to replace soil. Mediokres has been widely marketed in Indonesia However, in the production process of mediokres, there is the obstacle, one of which is the supply of mediokres products which is slow compared to the large consumer demand. Therefore the formed mediokres community is able to help meet the mediokres stock both for ordering and stocking every month. So that consumer demand is fulfilled.
\end{abstract}

(C) 2020 Wiwit Probowati, Ika Afifah Nugraheni, Suryadi. Published by Institute for Research and Community Services Universitas Muhammadiyah Palangkaraya. This is Open Access article under the CC-BY-SA License (http://creativecommons.org/licenses/by-sa/4.0/). DOI: https://doi.org/10.33084/pengabdianmu.v5i2.1067

\section{PENDAHULUAN}

Setengah abad yang lalu masyarakat belum banyak mengenal plastik. Mereka lebih banyak menggunakan berbagai jenis bahan organik. Pada dekade tujuh puluhan orang masih menggunakan tas belanja dari rotan, bambu, wadah makan dan membungkus makanan dengan daun jati/ daun pisang. Sedangkan sekarang kita berhadapan dengan barang-barang sintetis sebagai pengganti bahan organik yaitu bahan-bahan dari plastik (Alqa et al., 2018). Plastik adalah salah satu bahan yang dapat kita temui di hampir setiap barang. Mulai dari botol minum, alat makanan (sendok, garpu, wadah, gelas), kantong pembungkus/kresek, TV, kulkas, pipa pralon, plastik laminating, sikat gigi, compact disk (CD), kutex (cat kuku), mainan anak-anak, mesin, alat-alat militer hingga pestisida. Menurut penelitian, penggunaan plastik yang tidak sesuai persyaratan akan menimbulkan berbagai gangguan kesehatan, karena dapat mengakibatkan pemicu kanker dan kerusakan 
jaringan pada tubuh manusia (karsinogenik). Selain itu plastik pada umumnya sulit untuk didegradasikan (diuraikan) oleh mikro organisme (Sarker et al., 2012).

Berbagai penelitian telah menghubungkan BisphenolA dengan dosis rendah dengan beberapa dampak terhadap kesehatan, seperti meningkatkan kadar prostat, penurunan kandungan hormon testoteron, memungkinkan terjadinya kanker payudara, sel prostat menjadi lebih sensitif terhadap hormon dan kanker, dan membuat seseorang menjadi hiperaktif (Setiawan \& Fitrah, 2018). Sampah plastik dapat bertahan hingga bertahun-tahun sehingga menyebabkan pencemaran terhadap lingkungan. Sampah plastik tidaklah bijak jika dibakar karena akan menghasilkan gas yang akan mencemari udara dan membahayakan pernafasan manusia, dan jika sampah plastik ditimbun dalam tanah maka akan mencemari tanah dan air tanah (Karuniastuti, 2013).

Plastik sendiri dikonsumsi sekitar 100 juta ton/tahun di seluruh dunia. Satu tes membuktikan 95\% orang pernah memakai barang mengandung Bisphenol-A. Oleh karena itu pemakaian plastik yang jumlahnya sangat besar tentunya akan berdampak signifikan terhadap kesehatan manusia dan lingkungan karena plastik mempunyai sifat sulit terdegradasi (nonbiodegradable), plastik diperkirakan membutuhkan 100 hingga 500 tahun hingga dapat terdekomposisi (terurai) dengan sempurna (Sahwan et al., 2005).

Menurut data BPS 2006 Indonesia telah memproduksi 65 juta ton sampah. Angka ini meningkat 1 juta dari tahun 2015 yang hanya 64 juta ton. Sampah yang dihasilkan 40 persennya adalah sampah plastik. Seperti yang kita ketahui bersama bahwa sampah plastik adalah salah satu sampah yang susah untuk terurai. Membutuhkan waktu bertahun-tahun untuk penguraian sampah. Masalah sampah tentu menjadi tanggung jawab kita bersama. Dampak yang telah ditimbulkan sampah berupa pencemaran udara, tanah dan air tentu ini juga memberikan dampak sosial (Siregar, 2014).

Pemerintah tentu tidak mampu untuk menanggulangi masalah diatas tanpa dukungan dari masyarakat. Sejauh ini pemerintah sudah mengampanyekan tentang $3 R$ yaitu Reduce (mengurangi penggunaan plastik), Reuse (menggunakan kembali/tidak sekali pakai) dan Recycle (mendaur ulang). Menurut Winarti dan Azizah (2016), untuk menanggulangi pencemaran lingkungan dibutuhkan kebijaksanaan masyarakat dalam mengelola sampah khususnya sampah plastik (kresek). Setiap rumah tangga sebaiknya memiliki bak sampah yang telah dipilah antara sampah organik dan anorganik. Selanjutnya, dilakukan pengolahan sampah untuk menjadi hal yang lebih bermanfaat (Tubnonghe et al., 2010).

Desa Margomulyo merupakan salah satu desa yang berada di Kecamatan Seyegan Kabupaten Sleman, Daerah Istimewa Yogyakarta yang kami jadikan proyek percontohan Program Kemitraan Masyarakat. Desa Margomulyo telah memiliki dua titik lokasi pengumpulan sampah yaitu di dusun Mangsel dan dusun Kamal wetan. Desa Margomulyo telah memiliki dua titik lokasi pengumpulan sampah yaitu di dusun Mangsel dan dusun Kamal wetan. Pengumpulan sampah ini bersifat sementara karena setiap bulan akan diangkut ke Tempat Pembuangan Sampah Akhir (TPA) di Piyungan Kabupaten Bantul. Wrga masyarakat masih mengeluhkan tidak adanya pengolahan sampah plastik yang merusak lingkungan dan apabila dibakar menimbulkan polusi udara.

Sementara itu di dusun tetangga yaitu dusun Sayidan Desa Sumberadi Kecamatan Mlati yang jaraknya kurang lebih 1 Kilometer dari desa Margomulyo sudah terdapat Organisasi UKM yang bergerak di bidang pengolahan sampah plastik khususnya plastik kresek. Sebutlah Bapak Suryadi sebagai penemu sekaligus pengelola 
pembuatan media tanaman dari plastik kresek. Beliau merintis usaha ini demi misinya menyelamatkan lingkungan dari sampah plastik sejak 2006, dan sampai sekarang usaha tersebut sudah membuahkan hasil dengan diurusnya hak paten atas temuannya itu di Kementerian Hukum dan Hak Azasi Manusia. Media tanam berupa plastik kresek bernutrisi ini diolah oleh pak Suryadi sendiri dan dibantu oleh warga. Namun dalam penyebarannya belum begitu banyak yang tahu dan belum terbentuk komunitas pengolah sampah plastik kresek menjadi media tanam. Oleh karena itu dalam program pengabdian masyarakat ini di desa tetangga yaitu Margomulyo khususnya dusun Kamal wetan akan disosialisasikan tentang teknik pembuatan media tanam dari plastik kresek. Terbentuknya komunitas masyarakat pengolah sampah plastik menjadi media tanam selain dapat meningkatkan perkonomian warga juga dapat mengurangi sampah plastik kresek di kabupaten Sleman.

Permasalahan global yang dialami berbagai daerah di Indonesia adalah sampah. Baik di daerah perkotaan maupun desa masih banyak yang mengalami kesulitan dalam mengolah dan memanfaatkan sampah terutama sampah plastik. Dapat dikatakan plastik kresek merupakan kebutuhan primer pedagang atau bidang usaha lain untuk membungkus produk dagangan yang dibeli konsumen (Probowati \& Isworo, 2019). Hal ini menjadikan sampah plastik kresek menjadi yang terbanyak memenuhi bak sampah maupun Tempat Pembuangan Akhir.

Plastik kresek tergolong sampah anorganik yang sulit untuk terdekomposisi di dalam tanah. Waktu yang dibutuhkan plastik kresek untuk hancur secara alami sampai 50 tahun lebih ditambah material yang terkandung dalam plastik merupakan racun bagi tanah, air dan mikroorganisme baik di dalam tanah (Purwaningrum, 2016). Selain itu penanganan sampah plastik kresek yang dibakar dapat mencemari udara dan lingkungan oleh zat kimia toksik yang terkandung dalam plastic (Karuniastuti, 2013). Penanganan limbah plastik kresek sangat memerlukan perhatian yang serius terutama dalam pengendalian produksinya, regulasi penggunaan di pasaran dan sosialisasi kesadaran masyarakat akan bahaya plastik kresek. Plastik kresek di TPA mempunyai harga jual yang rendah untuk didaur ulang, selain itu produk plastik kresek yang mudah terurai juga masih belum banyak di pasaran. Pedagang lebih memilih menggunakan plastik kresek biasa yang sulit terdekomposisi dalam tanah.

Sebuah terobosan baru dari Usaha Kecil dan Menengah (UKM) Sayidan Agro Media mampu menjawab permasalahan sampah plastik kresek dari segi pemanfaat limbah. Penemuan bapak Suryadi yang telah diakui penemuannya oleh Kementerian Hukum dan Hak Azasi Manusia Republik Indonesia yaitu produk pengolahan plastik kresek menjadi media tanam pengganti tanah. Media tanam dari plastik kresek (mediokres) yang telah diberi formula pupuk organik mampu menjadi media tanam menggantikan tanah untuk berbagai jenis tanaman yang dapat digunakan bertahun-tahun sampai plastik tersebut terdegradasi. Produk mediokres dinilai oleh Pemerintah daerah Sleman sebagai inovasi baru untuk mengurangi sampah plastik kresek dan merupakan bentuk energi terbarukan apabila lahan bercocok tanam di perkotaan sudah semakin sedikit.

Usaha Kecil dan Menengah Sayidan Agro Media menjadi pelopor gerakan diet konsumsi plastik kresek. Usaha pengolah sampah plastik kresek menjadi media tanam ini sudah berjalan sejak tahun 2016. Selama 3 tahun ini mengalami berbagai tantangan dan hambatan. Produk mediokres secara rutin dipasok ke Taman Mini Indonesia Indah, TVRI Jogja, LSM Penggiat Lingkungan Hidup, berbabagi pameran di Yogyakarta sampai manca 
negara dan dilanggan oleh masyarakat perkotaan yang sudah melek akan mediokres. Tujuan yang ingin dicapai dalam program pengabdian masyarakat ini adalah memotivasi warga masyarakat untuk bergabung dalam komunitas pengolah sampah plastik serta mempercepat produksi mediokres dan meningkatkan pemasaran produk.

\section{METODOLOGI}

Persiapan berbagai alat bahan yang mendukung pelaksanaan penyuluhan dan pelatihan pembuatan media tanam dari plastik kresek (mediokres).

Ada beberapa tahap dalam pembuatan mediokres. Tahapannya adalah sortasi, pemotongan, pembentukan dan pencampuran nutrisi.

1. Sortasi merupakan proses pemilahan plastik yang akan digunakan untuk membuat mediokres. Pemilihan ini bisa dilakukan dengan cara memilah berdasarkan warna plastik. Setelah itu dilakukan pencucian untuk menghilangkan kotoran yang ada pada plastik. Selanjutnya adalah mengeringkan plastik dengan cara menjemur dan mengankinnya.

2. Pemotongan dilakukan sebagai upaya untuk mempermudah pembentukan mediokres. Pemotongan bisa dilakukan dengan cara memotong bagiaan plastik dengan bentuk kotak.

3. Langkah selanjutnya adalah pembentukan yang dilakukan dengan cara membentuk plastik membentuk bulatan. Dibutuhkan keahlian khusus dalam pembentukan ini.

4. Plastik yang sudah dibentuk selanjutnya dicampurkan dengan nutrisi. Sebelumnya campuran nutrisi harus dibuat terlebih dahulu. Sediakan air sebanyak 10 liter dan campurkan nutrisi sebanyak $1 / 2$ liter aduk sampai merata. Setelah itu masukkan mediokres kedalam campuran nutrisi. Nutrisi yang digunakan terdiri dari pupuk organik cair yang telah diracik. Lakukan perendaman mediokres selama 12 jam dan diaduk setiap 30 menit sekali

5. Tahap pelatihan pembuatan media tanam dari plastik kresek

Setelah penyuluhan, selanjutnya dilakukan pelatihan pembuatan media tanam dari plastik kresek. Hal ini dimaksudkan agar warga sasaran tidak hanya mendapatkan pengetahuan, tetapi juga ketrampilan untuk membuat media tanam dari plastik kresek. Sehingga diharapkan memotivasi jiwa kewirausahaan warga untuk mendukung produktivitas bangsa sebagaimana yang tertuang dalam program nawacita pemerintah. Warga masyarakat yang dilatih ini kemudian dimantapkan dan dicatat sebagai komunitas pembuat mediokres. Setiap bulan komunitas tersebut ditarget menyetorkan mediokres kepada Sayidan Agro Media agar pasokan produksi mediokres mengalami peningkatan dan permintaan konsumen terlayani

\section{HASIL DAN PEMBAHASAN}

Berawal dari keprihatinan kondisi lingkungan di sekitar rumah dimana tempat pembuangan akhir sampah dipenuhi sampah plastik kresek yang tidak ikut tersortir. Kantong plastik atau biasa disebut plastik kresek adalah penemuan paling berharga yang dapat menggantikan daun pisang, daun jati dan material organik lainnya sebagai pembungkus makanan. Plastik kresek mempunyai kelebihan kedap air, tidak memakan tempat banyak dan praktis. Namun, manfaat yang didapatkan ini tidak sebanding dengan dampak buruk bagi lingkungan dan kesehatan dalam penggunaannya (Karuniastuti, 2013). Masyarakat yang dengan mudah menggunakan kantog plastik untuk pembungkus makanan ataupun kantong belanja apabila dibuang akan menjadi sampah yang mencemari lingkungan. Pada dunia jual beli barang bekas plastik maupun kaleng, plastik kresek menempati posisi sampah yang paling 
tidak bernilai jual. Daya daur ulang yang relatif kecil karena sudah termasuk bentuk plastik yang paling sederhana dan harga jual juga relati rendah dibandingkan dengan botol plastik bekas minuman ataupun kertas bekas. Sehingga kehadirannya di tempat pembuangan akhir sampah sangat mengganggu.

Sayidan Agro Media adalah organisasi yang bergerak di bidang penyelamat lingkungan dari sampah plastik kresek. Plastik kresek dari TPA ini diolah menjadi bulatan plastik yang dapat digunakan sebagai media tanam pengganti tanah.

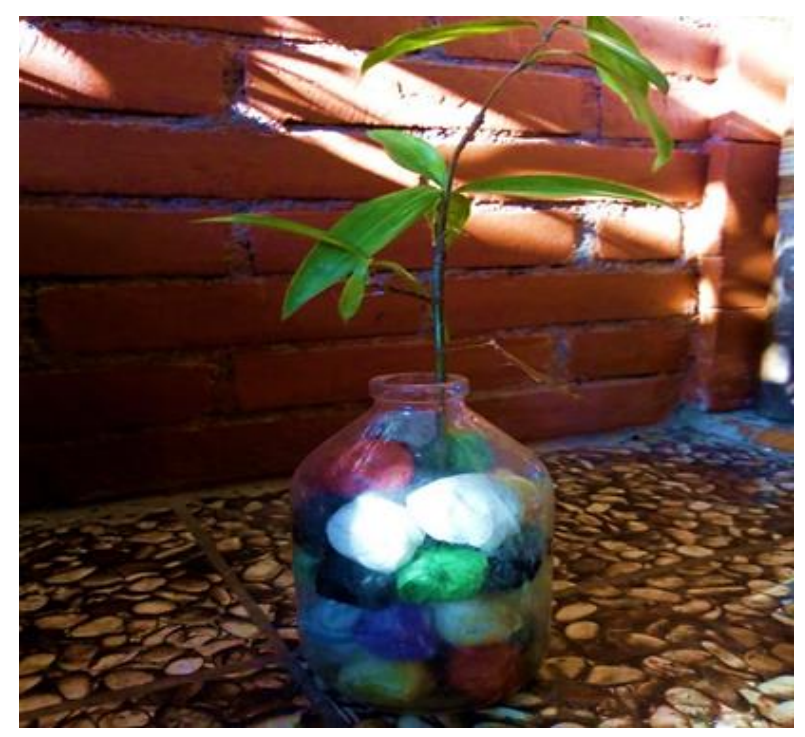

Gambar 1. Media tanam dari plastik kresek pengganti tanah.

Bulatan plastik yang dijadikan media tanam ini sudah mengandung nutrisi yang diracik sesuai kebutuhan tanaman. Media tanam dari plastik kresek biasa disebut mediokres. Mediokres merupakan inovasi organisasi Sayidan Agro Media yang telah tersertifikasi hak paten atas ciptaannya di Kementerian Hukum dan Hak Asasi Manusia pada 9 Oktober 2018 dengan Nomor Paten IDS000001969. Namun produksi mediokres ini sudah dimulai sejak tahun 2016. Sayidan Agro Media juga telah melakukan publikasi melalui media massa, televisi dan aktif mengikuti pameran potensi daerah. Konsumen mediokres adalah warga perkotaan yang mana lingkungan sudah tidak banyak lahan kosong untuk bercocok tanam. Selama ini mediokres diproduksi oleh Sayidan Agro Media melalui sistem borongan yang dilakukan oleh warga sekitar apabila ada pesanan yang banyak. Sehingga tidak ada karyawan yang rutin setiap hari memproduksi mediokres ini. Akibatnya apabila ada pesanan dalam jumlah banyak sedangkan stok produk habis maka akan menjadi proyek dadakan bagi warga sekitar. Oleh karena itu pengabdian masyarakat ini berjalan untuk menjembatani kekurangan dalam manajemen organisasi dengan kondisi masyarakat yang masih sederhana.

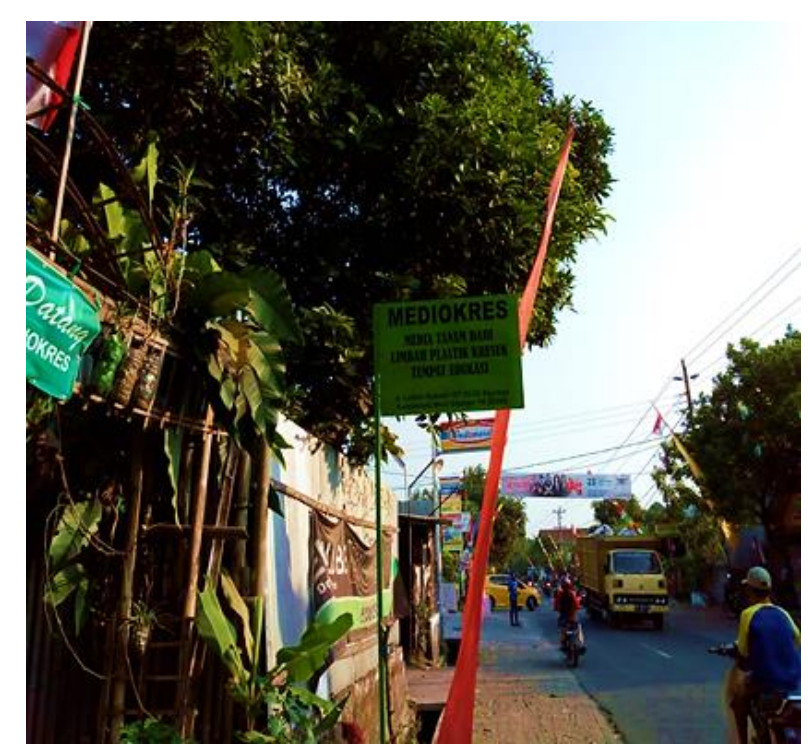

Gambar 2. Pusat produksi mediokres oleh Sayidan Agro Media.

Pada pengabdian masyarakat ini dilakukan sosialisasi kepada warga masyarakat desa Margomulyo yang lokasinya berada di dekat TPA. Sosialisai awal dilakukan dengan memaparkan keprihatinan lingkungan akibat sampah plastik. Setelah pendekatan berhasil membuka cara pandang warga masyakarat kemudian dilanjutkan sosialisasi lanjut terkait mediokres. Selanjutnya warga terpilih yang mempunyai komitmen dalam penanggulangan sampah melalui mediokres dapat dilatih untuk membuat mediokres. Pelatihan ini 
dilakukan selama satu minggu sampai pengemasan produk mediokres.

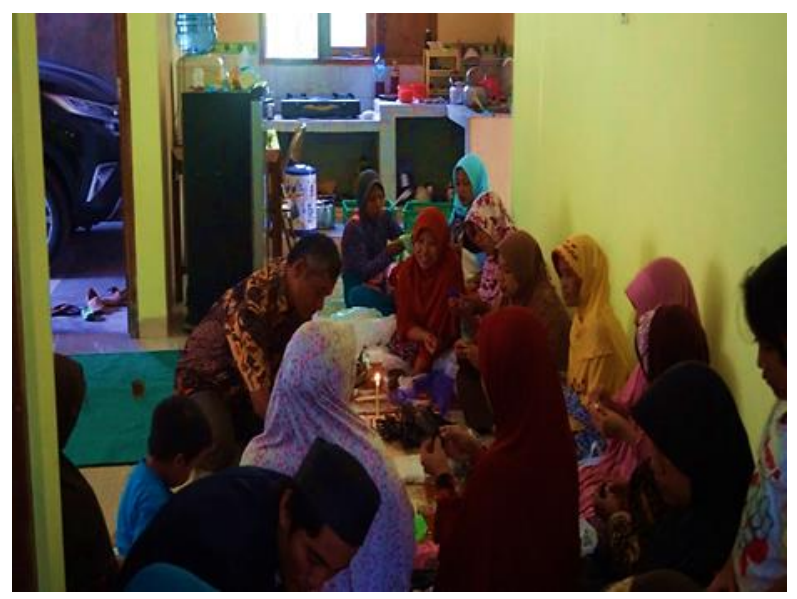

Gambar 3. Sosialisasi dan pelatihan pembuatan mediokres warga desa Margomulyo.

Selama proses sosialisasi dan pelatihan banyak warga masyarakat yang tergugah akan program pengabdian masyarakat ini, kemudian bersedia bekerja untuk memasok mediokres setiap bulan. Tercatat dalam program pengabdian masyarakat ini ada 30 warga yang bersedia menjadi membantu memasok mediokres. Produk mediokres disetorkan komunitas ini setiap bulan dalam bentuk bulatan plastik belum diberi nutrisi dan belum dikemas. Perendaman nutrisi dan pengemasan tetap dilakukan di Sayidan Agro Media.

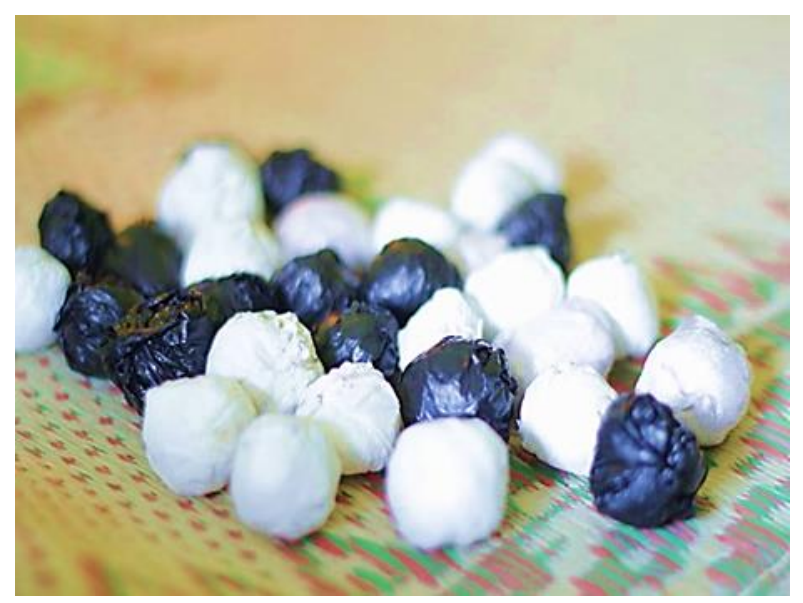

Gambar 4. Bulatan plastik kresek yang siap direndam nutrisi tanaman (pupuk organik cair).

Komunitas dilatih untuk membuat bulatan mediokres yang memerlukan teknik khusus. Teknik ini tidak dilakukan dengan meremas atau melipat-lipat lembaran plastik sampai membentuk bulatan, tetapi ada gerakan kombinasi meremas dan memilin secara perlahan sampai membentuk bulatan sempurna. Penelitian mengenai ukuran dan bentuk mediokres telah dilakukan sebelumnya oleh organisasi ini dan bentuk bulat dan diameter $2 \mathrm{~cm}$ inilah yang paling optimal dalam menyerap pupuk organik cair bagi tanaman. Penyortiran ukuran mediokres dari komunitas juga dilakukan oleh Sayidan Agro Media agar pada saat perendaman dan pengemasan sudah terstandarisasi.

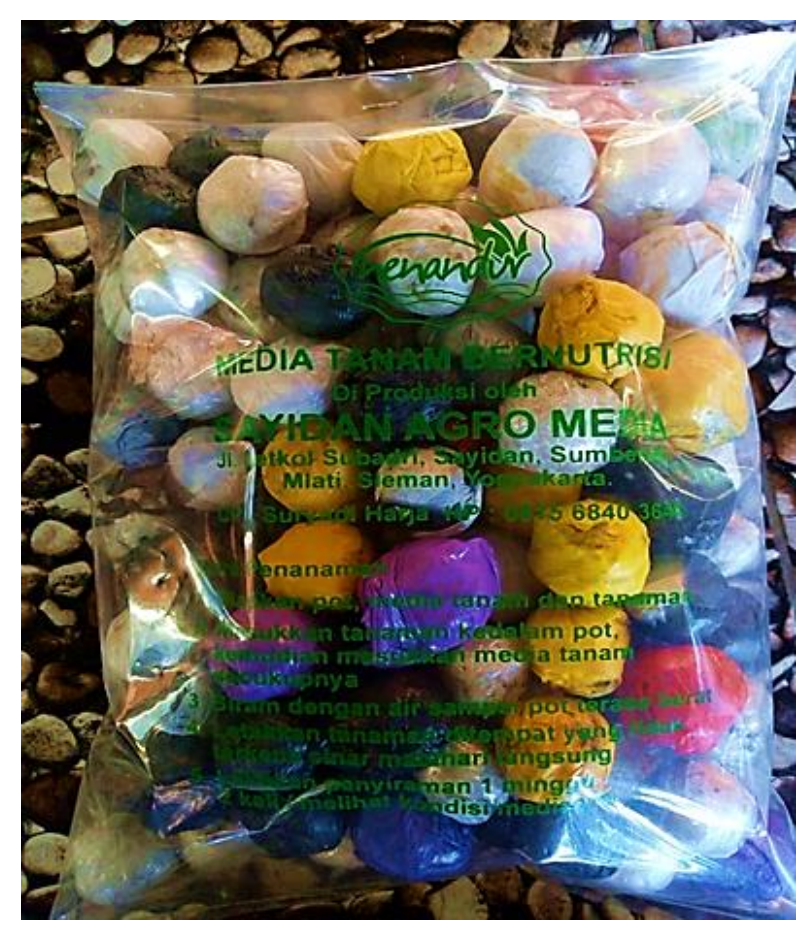

Gambar 5. Produk mediokres yang siap untuk dijual.

Monitoring dan evaluasi kinerja komunitas pembuat mediokres ini terus dipantau melalui program pengabdian masyarakat. Semenjak komunitas tersebut aktif membuat dan memasok mediokres, pasokan mediokres terus bertambah. Sehingga permintaan konsumen terlayani dengan baik dan pangsa pasar mediokres semakin luas. 


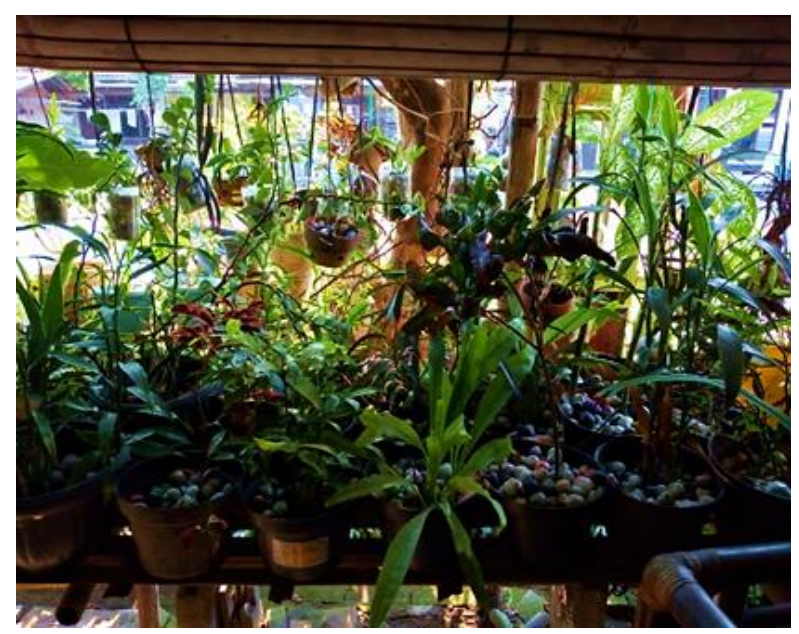

Gambar 6. Salah satu taman rumah yang menggunakan mediokres untuk media tanam.

Program pengabdian masyarakat ini membuka kepekaan masyarakat akan kondisi lingkungan yang sudah tercemar sampah plastik. Komunitas mediokres yang terbentuk juga dapat meningkatkan perekonomian mereka dengan menjual mediokres ke Sayidan Agro Media. Sehingga terjadi simbiosis mutualisme diantara kedua belah pihak.

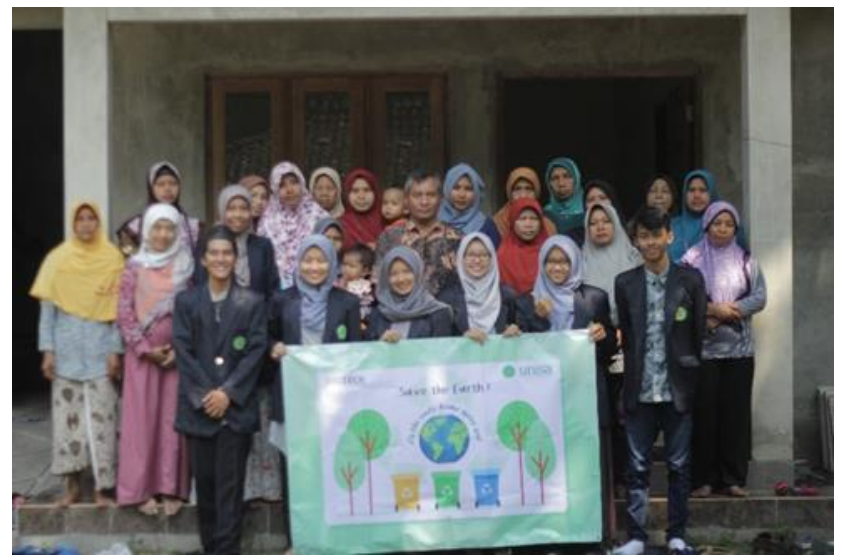

Gambar 7. Foto bersama tim pengabdian masyarakat Universitas 'Aisyiyah Yogyakarta dengan komunitas mediokres.

\section{KESIMPULAN}

Media tanam dari plastik kresek (mediokres) dapat menjadi solusi atas permasalahan sampah plastik kresek yang memenuhi Tempat Pembuangan Akhir Sampah dan tidak mempunyai harga jual. Mediokres dapat diproduksi lebih banyak dan mampu memenuhi permintaan konsumen yang semakin meningkat. Komunitas ini semoga dapat bekerjasama dan terus mendukung organisasi Sayidan Agro Media dalam menjalankan misi menyelamatkan lingkungan dari plastik.

\section{UCAPAN TERIMA KASIH}

Penulis mengucapkan terima kasih kepada Lembaga Penelitian dan Pengabdian Masyarakat (LPPM) Universitas 'Aisyiyah Yogyakarta atas dukungan dana penelitian melalui hibah internal grant.. Penulis juga berterimakasih kepada organisasi Sayidan Agro Media yang telah bekerjasama dan melakukan konsolidasi dengan masyarakat desa Margomulyo, kecamatan Seyegan, kabupaten Sleman.

\section{REFERENSI}

Alqa, A.S.F., Zuliantoni, Z., Gunawan, A. 2018. Pengolahan Limbah Plastik Berbasis Mitra Berkegiatan Lingkungan. Jurnal Pengabdi. 1(2):77-85. http://dx.doi.org/10.26418/jplp2km.v1i2.299 06

Karuniastuti, N. 2013. Bahaya Plastik Terhadap Kesehatan Dan Lingkungan. Swara Patra: Majalah Ilmiah PPSDM Migas. 3(1):6-14.

Probowati, W., Isworo, A. 2019. Nilai Ta'awun dari Sampah. Suara Muhammadiyah. https://www.suaramuhammadiyah.id/2019 /01/29/nilai-taawun-dari-sampah/

Purwaningrum, P. 2016. Upaya Mengurangi Timbulan Sampah Plastik Di Lingkungan. Indonesian Journal of Urban and Environmental Technology. 8(2):141-147.

http://dx.doi.org/10.25105/urbanenvirotech .v8i2.1421

Sahwan, F.L., Martono, D.H., Wahyono, S., Wisoyodharmo, L.A. 2005. Sistem Pengolahan Limbah Plastik di Indonesia. Jurnal Teknologi Lingkungan. 6(1):311-318. https://doi.org/10.29122/jtl.v6i1.330 
Sarker, M., Rashid, M.M., Rahman, M.S., Molla, M. 2012. Environmentally Harmful Low Density Waste Plastic Conversion into Kerosene Grade Fuel. Journal of Environmental Protection. 3(8):700-708. http://dx.doi.org/10.4236/jep.2012.3808 3

Setiawan, B., Fitrah, D.S. 2018. Kampanye Gerakan Indonesia Diet Kantong Plastik Dalam Membentuk Persepsi Masyarakat Bandung. Jurnal Manajemen Komunikasi. 2(2):102-117.

https://doi.org/10.24198/jmk.v2i2.1290 9

Siregar, C.N. 2014. Partisipasi Masyarakat Dan Nelayan Dalam Mengurangi Pencemaran Air Laut Di Kawasan Pantai ManadoSulawesi Utara. Jurnal Sosioteknologi. 13(1):25-33.

http://dx.doi.org/10.5614/sostek.itbj.20 14.13.1.3

Tubnonghee, R., Sanongraj, S., Sanongraj, W. 2010. Comparative Characteristics of Derived Plastic Oil and Commercial Diesel Oil. In Proceeding of the 8th Asian-Pacific Regional Conference on Practical Environmental Technologies (APRC2010). Thailand, Ubonratchathani: Ubon Ratchathani University.

Winarti, P., Azizah, A. 2016. Penyuluhan Pengelolaan Sampah Plastik Dengan Konsep Zero Waste Bagi Ibu Rumah Tangga Dikecamatan Bergas Kabupaten Semarang. E-Dimas: Jurnal Pengabdian kepada Masyarakat. 7(1):60-67. http://dx.doi.org/10.26877/e-

dimas.v7i1.1039 